\title{
VIEWPOINT Dynamic tools unify fragmented $4 R s$ into an integrative nitrogen management approach
}

\author{
Shai Sela and Harold M. van Es
}

$\mathbf{N}$ itrogen $(\mathrm{N})$ is an essential nutrient for crop production, and the manufacture of synthetic $\mathrm{N}$ fertilizer has facilitated impressive advances in food production that have assisted in the avoidance of widespread hunger despite a rapidly growing twentieth century global population. However, this nutrient also causes major environmental concerns, including nitrate $\left(\mathrm{NO}_{3}{ }^{-}\right)$contamination of groundwater in agricultural regions and hypoxia and dead zones in estuaries. Also, gaseous forms of $\mathrm{N}$ contribute to air quality issues. Nitrous oxide $\left(\mathrm{N}_{2} \mathrm{O}\right)$, a potent greenhouse gas, contributes to climate change, and ammonia $\left(\mathrm{NH}_{3}\right)$ emissions contribute to fine particulate air pollution, a cause of respiratory diseases (Pinder et al. 2007). Anthropogenic $\mathrm{N}$ pollution, therefore, has large social costs, with estimated potential ecosystem and health damages of US $\$ 157$ billion annually (Sobota et al. 2015). Despite many mitigation efforts, the $\mathrm{N}$ loss from agricultural systems continues to be a major concern, and in 2017 the hypoxic zone in the Gulf of Mexico reached the greatest extent ever recorded (NOAA 2017).

There is a pressing need to improve the management of agricultural $\mathrm{N}$, and the $4 \mathrm{R}$ concept has been proposed as a conceptual path toward more efficient $\mathrm{N}$ management (Snyder et al. 2009; TFI 2017). This approach promotes field application of nutrients from the right source, at the right place, right time and right rate. As a concept, the $4 \mathrm{R}$ approach is straightforward and has the potential to steer growers toward managing crop $\mathrm{N}$ more efficiently. However, under the complexity of real production environments in farmer fields, effective implementation of the $4 \mathrm{R}$ concept is challenging. The "right" answer to each $\mathrm{R}$ factor, especially for $\mathrm{N}$ rate, remains an elusive concept that varies spatially among or within fields, as well as

Shai Sela is a postdoctoral associate and Harold $M$. van Es is a professor of soil science, both at the Section of Soil and Crop Sciences, School of Integrated Plant Science, Cornell University, Ithaca, New York. temporally for the same field location. We submit that tools that integrate these management concepts and dynamically adapt $\mathrm{N}$ management to the localized conditions of the production environment could play a central role in unifying these fragmented $4 \mathrm{R}$ components into a coherent $\mathrm{N}$ management approach.

\section{R NUTRIENT STEWARDSHIP}

The basic advantages of $4 \mathrm{R}$ nutrient stewardship could be summarized as follows.

Nitrogen Source. Many studies found that modifying the source of $\mathrm{N}$ inputs can reduce losses. Especially Enhanced Efficiency Compounds (EECs), such as nitrification or urease inhibitors, can delay $\mathrm{N}$ transformations and result in reduced loss potential of soil N (Abalos et al. 2014; Halvorson et al. 2014; Yang et al. 2016). The benefits of using EECs are expected to be higher in production environments that are more prone to $\mathrm{N}$ losses, such as very coarse or fine soil textures in humid climates. However, the quantitative agronomic, environmental, and economic benefits of EECs remain difficult to predict for diverse production environments.

Nitrogen Placement. The precise location of fertilizer $\mathrm{N}$ application can affect $\mathrm{N}$ losses and thereby crop availability. Incorporated applications, for example, are expected to increase crop $\mathrm{N}$ availability compared to surface broadcasting (see Nkebiwe et al. [2016] for a recent review), especially when the formulation is susceptible to losses through volatilization (Rochette et al. 2009). Banding of $\mathrm{N}$ application, e.g., through injectors or drop tubes, can also increase $\mathrm{N}$ availability by applying the product closer to the crop roots (Schroder et al 2015; Westerschulte et al. 2017). However, there is uncertainty regarding the quantitative gains of such practices in different production environments.

Timing of Nitrogen Application. The scheduling of $\mathrm{N}$ application affects the ability to synchronize crop $\mathrm{N}$ availability with crop $\mathrm{N}$ needs, which is known to minimize environmental losses. According to USDA data (USDA ERS 2010), only about a third of US corn (Zea mays L.) growers apply fertilizer $\mathrm{N}$ within the active growing season, with the remainder applying either in the fall, in the spring, or both. While there are logistical advantages to applying $\mathrm{N}$ prior to the growing season, these early applications also increase the risk of $\mathrm{N}$ losses, especially under humid climate conditions. In a multiyear simulation study including 19 midwestern locations, split applications where the majority of $\mathrm{N}$ is applied within the growing season required on average $50 \%$ and $40 \%$ less $\mathrm{N}$ than fall and spring preplant $\mathrm{N}$ applications, respectively (McLellan et al. 2018). Conversely, other studies found mixed or no agronomic or environmental benefits in shifting $\mathrm{N}$ application from spring to starter plus sidedress (Kovács et al. 2015; Pittelkow et al. 2017). In general, it is challenging for growers to understand the field and climate conditions that benefit from modifying the timing of $\mathrm{N}$ application in the context of logistical and economic considerations.

Nitrogen Application Rate. Estimating the correct $\mathrm{N}$ rate needed for a given production location (field, zone, etc.) at an optimum time to reach an expected yield is both challenging and elusive. Optimal $\mathrm{N}$ rates vary from field to field and season to season, depending on multiple governing factors such as soil texture, weather, $\mathrm{N}$ mineralization rates, prior and future $\mathrm{N}$ losses, organic $\mathrm{N}$ inputs, and yield potential. The amount of $\mathrm{N}$ applied is closely tied to the timing of applications, and also the form and placement of the $\mathrm{N}$ applied, i.e., the right $\mathrm{N}$ rate cannot be uncoupled from decisions on the other $3 \mathrm{Rs}$ as they affect the dynamic transformations and losses.

\section{ADDITIONAL FACTORS}

The 4R concept could be extended to include more factors involving additional management practices. These include (1) irrigation and drainage management, which impact yield and the potential for $\mathrm{N}$ leaching and denitrification losses and associated crop $\mathrm{N}$ availability; (2) soil health management, affecting among others soil structure and organic matter 
content and quality, and thereby $\mathrm{N}$ losses and availability; (3) crop management through precision seeding and locationadapted crop genetics; and (4) optimized use of other agronomic inputs that affect crop growth, including management of $\mathrm{pH}$, other nutrients, pest control, etc. These factors all affect the ability to optimize the management of $\mathrm{N}$, especially to determine the right $\mathrm{N}$ rate. Together, we refer to the broader use of best $\mathrm{N}$ management practices as $4 \mathrm{R}+$.

\section{APPROACHES TO DYNAMIC NITROGEN MANAGEMENT}

Considering the complexity of the processes involving $\mathrm{N}$ management, multiple decision tools have been developed to aid growers. These are generally based on long-term yield response data and involve $\mathrm{N}$ recommendations that are mostly unchanged by field or season-specific conditions (Morris et al. 2018). A more recently advocated "adaptive management" approach in this context promotes a gradual trial-and-learn methodology based on implementation of practices followed by evaluation (e.g., end-of-season measures of crop performance) and subsequent interpretation and improvement (Morris et al. 2018). However, $\mathrm{N}$ in fields is highly changeable and subject to rapid and sizable transformations that markedly impact crop $\mathrm{N}$ availability and loss potential-mostly as a result of weather events. More integrative and dynamic approaches for $\mathrm{N}$ management need to be adopted that incorporate real-time and site-specific adaptation, i.e., precision management where $\mathrm{N}$ rates are determined through current accounting of the continually changing space and time conditions of the production environment. These, in turn, are impacted by production (e.g., $\mathrm{N}$ sources and timing) and environmental (e.g., weather and soil) factors. Three approaches are most commonly pursued: (1) soil testing, (2) proximal or remote crop sensing, or (3) dynamic modeling.

Soil tests, notably the widely used PreSidedress Nitrate Test (PSNT) (Magdoff et al. 1984), are employed to estimate available soil mineral $\mathrm{N}$ levels (or sometimes labile organic $\mathrm{N}$ ) prior to fertilizer application. Indirectly, these tests incorporate the effects of recent weather and the $4 \mathrm{R}+\mathrm{fac}-$ tors by evaluating the resulting in-season soil $\mathrm{N}$ status. There are challenges in using these tests as they are labor intensive and somewhat imprecise (Klausner et al. 1993), especially with banded or injected prior fertilizer or manure applications. It may also be challenging to sample all relevant management zones or fields of interest within a short time window before sidedress time, and it is typically not feasible to use these tests frequently enough to regularly monitor seasonal soil $\mathrm{N}$ deficiencies. The in-field soil tests therefore offer a single snapshot of soil $\mathrm{N}$ in a specific time and location, and the results may become irrelevant if soil sampling is followed by unusual weather.

Plant $N$ status can be directly measured from leaf samples, but is generally more efficiently assessed through remote or proximal sensing of crop canopies from different platforms (satellite, aircraft, drone, or equipment-mounted; see Colaço and Bramley [2018] for a recent review). This allows monitoring of seasonal crop status in high spatial resolution and can generally facilitate variable $\mathrm{N}$ rate applications. These methods were found to deliver multiple benefits, such as reductions in the average amount of $\mathrm{N}$ applied and overall higher profitability over the grower regular practices (Scharf et al. 2011). Current challenges with the sensing approach to $\mathrm{N}$ management include the required reference strips with high $\mathrm{N}$ application rates, the indirect assessment of plant $\mathrm{N}$ needs, and detection problems at adequate plant $\mathrm{N}$ levels, confounding with water stress, as well as the remaining need to integrate risk and economic factors (Hatfield 2013).

Recent advances in data-driven computational and information technologies stimulated a new generation of dynamicadaptive $\mathrm{N}$ recommendation tools based on the application of mechanistic or stochastic models (Sela et al. 2016; Jin et al. 2017). These tools aim for real-time monitoring of soil and crop $\mathrm{N}$ status and, in most cases, recommend $\mathrm{N}$ application rates. As a management approach, simulation models are generally well suited to integrate $4 \mathrm{R}+$ factors and account for different soil, weather, and management factors (including formulation, placement, and timing of previous
$\mathrm{N}$ applications) to derive optimum $\mathrm{N}$ rates. The level of detail in accounting for the production environment complexity differs among tools, and models have been variably validated for different production environments. There is uncertainty associated with model inputs and outputs, and they vary in their ability to incorporate field observations. However, the ultimate use cost is low due to high scalability.

\section{A UNIFIED APPROACH TO INTEGRATING 4R+ COMPONENTS INTO NITROGEN MANAGEMENT}

The dynamic $\mathrm{N}$ management approaches presented here-soil testing, crop sensing, and model simulations-should not be considered as competing solutions. A way forward to managing $\mathrm{N}$ more efficiently and to fully incorporate the different elements of the $4 \mathrm{R}+$ concept could in fact be through the integration of different dynamic decision tools. In-field soil and tissue testing, for example, has strong observational power and could be used to calibrate and validate sensing platforms and models. Similarly, sensing data of crop and soil traits acquired during the growing season could be used to validate and adjust simulation predictions. This integrative approach could help gain efficiencies (e.g., reducing costs associated with expensive methods like PSNT sampling) and assimilate better decisions regarding all $4 \mathrm{R}+$ factors. In addition, retroactive simulation of past seasons with simulation models offers valuable insights on the longer-term benefits of improved $4 \mathrm{R}+\mathrm{N}$ management, e.g., the efficiency gains from EECs, the effect of different timings of $\mathrm{N}$ applications on optimum $\mathrm{N}$ rates, and improved water and soil health management in reducing $\mathrm{N}$ losses.

Figure 1 presents a conceptual model of how this framework could be applied to realize integrative $4 \mathrm{R}+$ management benefits. At any given time, soil and crop $\mathrm{N}$ status is the product of resource, management, and weather influences. Resource factors are mostly static aspects related to the production environment, i.e., soil type and health, and associated characteristics like texture, restrictive layers, organic matter content, rooting potential, etc. Within 
a given production environment, there are also multiple grower management factors that dynamically impact soil and crop $\mathrm{N}$ (e.g., prior manure or preplant $\mathrm{N}$; crop genetics; rotational and cover crop effects; and seeding timing and rates).

Weather plays a significant role in that precipitation and temperature affect soil $\mathrm{N}$ transformations, the transport and loss of different $\mathrm{N}$ species, and mineralization of $\mathrm{N}$ from organic sources. In conjunction with management decisions regarding other $4 \mathrm{R}+$ factors, these dynamically interact to create temporal and spatial variability in soil and crop N.This complexity could be effectively captured by software that incorporates simulation models, possibly augmented with field or remote sensing data (Jin et al. 2017).

Once the soil and crop $\mathrm{N}$ status in a particular location is estimated, stochastic projections can be incorporated including the expected yield, fertilizer and grain prices, future $\mathrm{N}$ losses due to weather effects, and asymmetric profit risks (higher cost from under-application vs. overapplication; figure 1). In all, this enables growers to make better decisions regarding in-season $\mathrm{N}$ recommendations and better integration of different $4 \mathrm{R}+$ components.

\section{APPLICATION OF A DYNAMIC MODEL TO A COMPLEX PRODUCTION ENVIRONMENT}

We used a model-based platform (the Adapt-N tool [Melkonian et al. 2008]) to explore the effects of different $4 \mathrm{R}+$ components on $\mathrm{N}$ dynamics and demonstrate its use to generate optimized $\mathrm{N}$ rate recommendations (Adapt-N was developed by Cornell University and is now one of several commercial model-based $\mathrm{N}$ management tools available to farmers). This example is not a full factorial evaluation of the impacts of all $4 \mathrm{R}+$ factors, but focuses on the effect of two components-right time and the right source-on the variability of soil and crop $\mathrm{N}$ at the time of sidedress, which in turn affect the most elusive $\mathrm{R}$ factor, the right $\mathrm{N}$ rate.

The Adapt-N tool includes soil hydrological and biogeochemical models as well as crop growth and $\mathrm{N}$ uptake routines, which are run on a daily time step using high-resolution weather observations

\section{Figure 1}

Conceptual model of integrating field complexity into fertilizer nitrogen $(\mathrm{N})$ rate decisions.
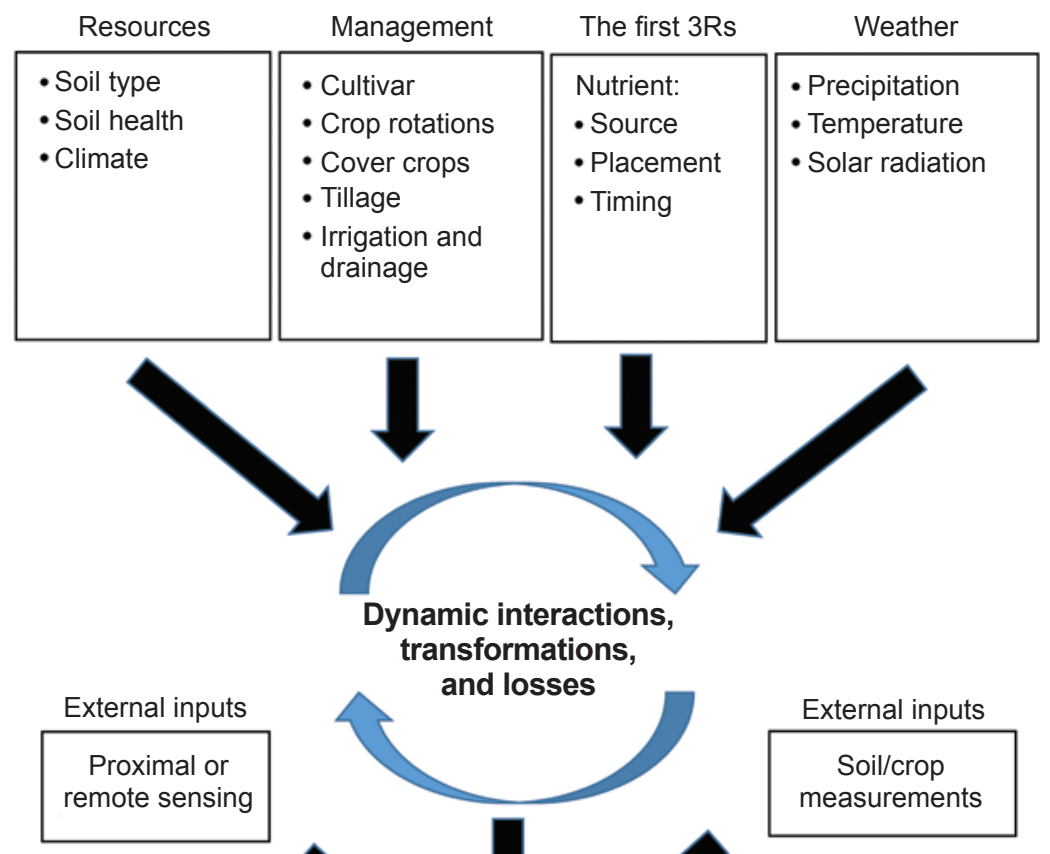
and losses

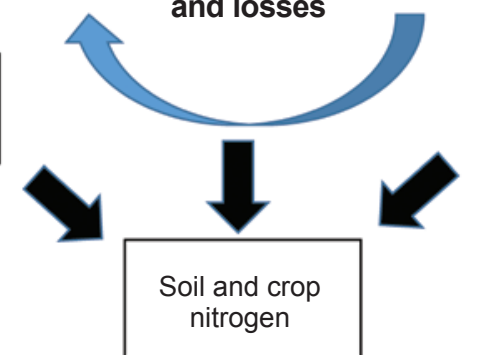

External inputs

Soil/crop measurements

Yield potential, grain and fertilizer prices, risk

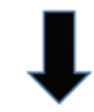

Right nitrogen rate

(Melkonian et al. 2008; Marjerison et al. 2016; Sela et al. 2016). The model addresses carbon (C) and $\mathrm{N}$ transformations and their modulation by temperature and moisture conditions, and accommodates input information on soil properties (e.g., texture and soil organic matter content) and $\mathrm{N}$ inputs (e.g., from fertilizer, manure, or rotations). It also accounts for different management factors such as tillage, $\mathrm{N}$ incorporation, irrigation, drainage, and cover cropping. The model provides $\mathrm{N}$ recommendations and also reports the simulated $\mathrm{N}$ leaching and gaseous losses. Observational inputs, such as measured soil $\mathrm{N}$ or the date of crop emergence, can be inputted by the user to adjust model simulations as the season progresses. Adapt-N generates near real-time (six hour lag) $\mathrm{N}$ rate recommendations through a mass balance equation in which components are estimated by dynamic simulations of the soil and crop environment (Sela et al. 2016).

We used the Adapt-N tool to generate $\mathrm{N}$ recommendations for a corn field in Iowa (figure 2). Excluding weather data, which were based on gridded data derived from actual station observations, the simulations were based on realistic scenario inputs. Notably, the soil texture was set as silt loam, and the soil organic matter at 3\%. The crop was planted on May 1, and the 


\section{Figure 2}

Location of the simulated corn field in the state of lowa. Background image source credit: ESRI world imagery base map.

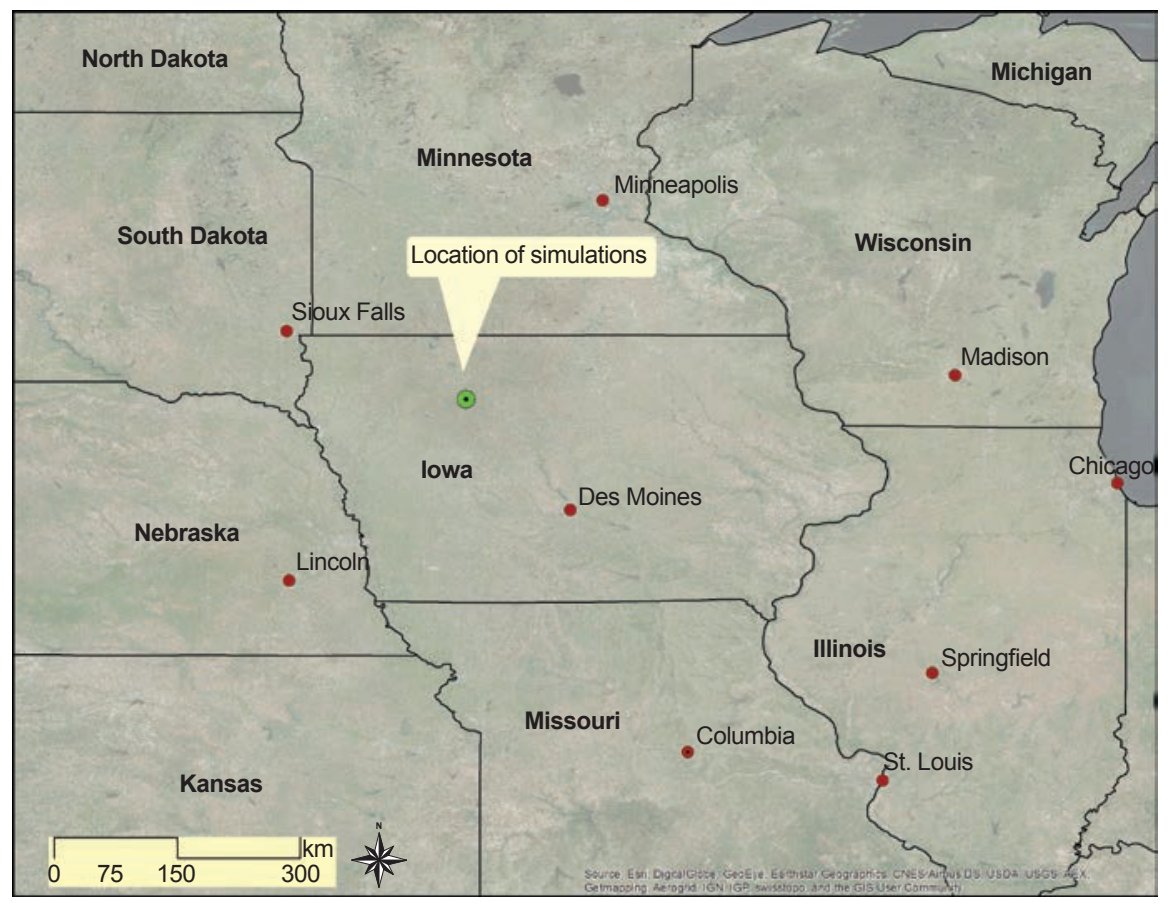

field yield potential was assumed at 13.8 $\mathrm{Mg} \mathrm{ha}{ }^{-1}\left(220 \mathrm{bu} \mathrm{ac}^{-1}\right)$. The simulations considered three timings of $\mathrm{N}$ application: (1) a fall preplant, applied on November 1 of the previous year; (2) a spring preplant, applied two weeks prior to planting; and (3) a starter plus sidedress scenario, where the majority of $\mathrm{N}$ is applied in-season. The preplant $\mathrm{N}$ rates were $247 \mathrm{~kg} \mathrm{ha}^{-1}(220 \mathrm{lb}$ $\mathrm{ac}^{-1}$ ) based on the assumption that each kilogram yield would require $0.0179 \mathrm{~kg}$ of $\mathrm{N}$ fertilizer (1 $\mathrm{lb} \mathrm{N} \mathrm{bu}^{-1}$ of yield). For the split application, we used a $34 \mathrm{~kg} \mathrm{ha}^{-1}$ $\left(30 \mathrm{lb} \mathrm{ac}^{-1}\right.$ ) starter rate. For the fall and spring preplant scenarios, the fertilizer was anhydrous ammonia $\left(\mathrm{NH}_{3}\right)$, while urea ammonium nitrate was used for the starter in the split $\mathrm{N}$ scenario. For the fall and spring scenarios we considered additional cases where an EEC was used (Nitrapyrin [2-chloro-6-(trichloromethyl) pyridine], a nitrification inhibitor).

In all simulations the Adapt- $\mathrm{N}$ tool was used at growth stage V6 to evaluate whether additional $\mathrm{N}$ was recommended to prevent $\mathrm{N}$ deficiencies, i.e., supplemental sidedress $\mathrm{N}$ was applied for all three scenarios when called for, rather than allowing yield forfeits from $\mathrm{N}$ deficiencies. The additional $\mathrm{N}$ was added to the total applied $\mathrm{N}$ reported. The simulations spanned eight years of climatic conditions (2010 to 2017).

Large variability in precipitation existed among the simulated seasons (tables 1 and 2; figure 3), which in turn drove differences in pre- and early-season $\mathrm{N}$ losses. Simulations suggest high variability in soil $\mathrm{N}$ at V6 for both the fall and spring application scenarios due to seasonal weather effects, with wide annual ranges of 194 and $138 \mathrm{~kg} \mathrm{ha}^{-1}$ (173 and $123 \mathrm{lb} \mathrm{ac}^{-1}$ ), respectively. Moving preplant applications from fall to spring reduces $\mathrm{N}$ losses and increases soil $\mathrm{N}$ at V6 by $45 \mathrm{~kg} \mathrm{ha}^{-1}$ (40 $\left.\mathrm{lb} \mathrm{ac}^{-1} ; 21 \%\right)$. Nitrogen losses by V6 are closely related to cumulative precipitation (figure 3a), with higher losses for the large preplant $\mathrm{N}$ scenarios. For the same growing season, soil $\mathrm{N}$ at V6 could vary markedly depending on application timing or the use of EECs (figure $3 \mathrm{~b}$ ). Higher soil $\mathrm{N}$ at V6 in the spring vs. fall preplant application scenario leads to lower $\mathrm{N}$ recommendations and an overall reduction of $18 \mathrm{~kg} \mathrm{ha}^{-1}\left(16 \mathrm{lb} \mathrm{ac}^{-1} ; 7 \%\right)$ in the total $\mathrm{N}$ application.

By applying the bulk of $\mathrm{N}$ immediately prior to the rapid $\mathrm{N}$ uptake phase, the starter plus sidedress $\mathrm{N}$ application scenario resulted in a further decrease in total $\mathrm{N}$ application of 107 (40\%) and 89 (36\%) kg $\mathrm{ha}^{-1}$ (95 and $79 \mathrm{lb} \mathrm{ac}^{-1}$ ) from the fall and spring scenarios, respectively. For the latter scenarios, simulation results suggest that EECs were effective mainly for the fall $\mathrm{N}$ preplant scenario, mostly in seasons with higher than average precipitation where it allowed a reduction of $24 \mathrm{~kg} \mathrm{ha}^{-1}$ (21 lb

\section{Table 1}

Nitrogen $(\mathrm{N})$ loss from November 1 until V6 crop stage and the resulting soil inorganic $\mathrm{N}$ for three $\mathrm{N}$ management scenarios. The mean value, the standard deviation (in parentheses), and the range are presented. Fall and spring scenarios received $247 \mathrm{~kg}^{-1}$ preplant $\mathrm{N}$, while starter received $34 \mathrm{~kg} \mathrm{ha}^{-1}$ at planting; all received additional sidedress $\mathrm{N}$ based on model-estimated needs to prevent yield forfeits.

\begin{tabular}{|c|c|c|c|c|c|c|}
\hline \multirow[b]{3}{*}{ Treatment } & \multicolumn{6}{|c|}{$\mathrm{N}$ management scenario } \\
\hline & \multicolumn{2}{|l|}{ Fall + sidedress } & \multicolumn{2}{|c|}{ Spring + sidedress } & \multicolumn{2}{|c|}{ Starter + sidedress } \\
\hline & $\begin{array}{l}\text { N loss by V6 } \\
\left(\mathrm{kg} \mathrm{ha}^{-1}\right)\end{array}$ & $\begin{array}{l}\text { Soil N at V6 } \\
\left(\mathrm{kg} \mathrm{ha}^{-1}\right)\end{array}$ & $\begin{array}{l}\text { N loss by V6 } \\
\left(\mathrm{kg} \mathrm{ha}^{-1}\right)\end{array}$ & $\begin{array}{l}\text { Soil N at V6 } \\
\left(\mathrm{kg} \mathrm{ha}^{-1}\right)\end{array}$ & $\begin{array}{l}\text { N loss by V6 } \\
\left(\mathrm{kg} \mathrm{ha}^{-1}\right)\end{array}$ & $\begin{array}{l}\text { Soil N at V6 } \\
\left(\mathrm{kg} \mathrm{ha}^{-1}\right)\end{array}$ \\
\hline No EEC & $143(63), 195$ & $208(62), 191$ & 96 (39), 120 & $256(41), 135$ & $51(18), 47$ & $88(19), 61$ \\
\hline With EEC & $128(55), 166$ & $223(55), 163$ & 84 (33), 100 & 267 (34), 114 & - & - \\
\hline All data & 136 (59), 197 & $216(59), 194$ & $90(36), 123$ & $261(38), 138$ & 51 (18), 47 & 88 (19), 61 \\
\hline
\end{tabular}

Notes: EEC = enhanced efficiency compound. 


\section{Table 2}

Sidedress nitrogen $(\mathrm{N})$ recommendation as generated by Adapt- $\mathrm{N}$ and the total $\mathrm{N}$ application for three $\mathrm{N}$ management scenarios. The mean value, the standard deviation (in parentheses), and the range are presented. Fall and spring scenarios received $247 \mathrm{~kg}$ $\mathrm{ha}^{-1}$ preplant $\mathrm{N}$, while starter received $34 \mathrm{~kg} \mathrm{ha}^{-1}$ at planting; all received additional sidedress $\mathrm{N}$ based on model-estimated needs to prevent yield forfeits.

\begin{tabular}{|c|c|c|c|c|c|c|}
\hline \multirow{3}{*}{ Treatment } & \multicolumn{6}{|c|}{ N management scenario } \\
\hline & \multicolumn{2}{|l|}{ Fall + sidedress } & \multicolumn{2}{|l|}{ Spring + sidedress } & \multicolumn{2}{|l|}{ Starter + sidedress } \\
\hline & SD N rec $\left(\mathrm{kg} \mathrm{ha}^{-1}\right)$ & Total N rec(kg ha $\left.{ }^{-1}\right)$ & SD N rec (kg ha-1) & Total $\mathrm{N}$ rec $\left(\mathrm{kg} \mathrm{ha}^{-1}\right)$ & SD N rec $\left(\mathrm{kg} \mathrm{ha}^{-1}\right)$ & Total N rec (kg ha-1) \\
\hline No EEC & 27 (40), 106 & 273 & 4 (11), 34 & 251 & 127 (18), 56 & 160 \\
\hline All data & 22 (35), 106 & 267 & $2(8), 34$ & 249 & $127(18), 56$ & 160 \\
\hline
\end{tabular}

Notes: SD N rec = sidedress $\mathrm{N}$ recommended. EEC = enhanced efficiency compound.

$\mathrm{ac}^{-1}$ ) in total $\mathrm{N}$ applied. These results highlight the complexity of soil $\mathrm{N}$ dynamics, which prevent conventional decision tools from integrating the $4 \mathrm{R}+$ factors into a meaningful $\mathrm{N}$ management strategy. This complexity could be addressed using correctly designed dynamic management tools.

\section{CONCLUSIONS}

This viewpoint submits that field observations, sensors, and especially model-based software are needed to translate the fragmented $4 \mathrm{R}+$ factors into an integrated management approach. A dynamic approach can more precisely estimate optimum $\mathrm{N}$ rates that are tailored to the location and time-specific conditions of the crop production environment under the grower-selected $4 \mathrm{R}+$ management approaches. This could be achieved using software comprising model simulations and economic routines, enhanced with observations from in-season soil testing or crop sensing. This also allows growers to evaluate the benefits of different management strategies under various seasonal weather scenarios as it relates to optimized $\mathrm{N}$ management. As such, this could be an influential factor in steering growers to adopt more sustainable $\mathrm{N}$ management practices in their production environment.

\section{ACKNOWLEDGEMENTS}

The Atkinson Center for a Sustainable Future (ACSF) at Cornell University and the Tulane Nitrogen Reduction Challenge Prize provided partial funding for this work.

\section{DISCLAIMER}

The Adapt-N tool was developed at Cornell University by Harold van Es and colleagues. Agronomic Technology Corporation (now part of
Yara International) received a license for its commercialization and partially sponsors Cornell research related to Adapt-N. All potential conflict of interests are actively managed per Cornell University guidelines.

\section{REFERENCES}

Abalos, D., S. Jeffery, A. Sanz-Cobena, G. Guardia, and A. Vallejo. 2014. Meta-analysis of the effect of urease and nitrification inhibitors on crop productivity and nitrogen use efficiency. Agriculture, Ecosystems, and Environment 189:136-144.

Colaço, A., and R. Bramley. 2018. Do crop sensors promote improved nitrogen management in grain crops? Field Crops Research 218:126-140.

Halvorson, A.D., C.S. Snyder, A.D. Blaylock, and S.J Del Grosso. 2014. Enhanced-efficiency nitrogen fertilizers: Potential role in nitrous oxide emission mitigation. Agronomy Journal 106:715-722.

Hatfield, J.L. 2013. Precision nutrient management and crop sensing. In Phenomics in Crop Plants: Trends, Options and Limitations, eds. J. Kumar et al. India: Springer.

Jin, Z.N., R. Prasad, J. Shriver, and Q.L. Zhuang. 2017. Crop model- and satellite imagery-based recommendation tool for variable rate $\mathrm{N}$ fertilizer application for the US Corn system. Precision Agriculture 18:779-800.

Klausner, S.D., W.S. Reid, and D.R. Bouldin. 1993 Relationship between late spring soil nitrate concentrations and corn yields in New York. Journal of Production Agriculture 6:350-354.

Kovács, P., G.E. Van Scoyoc, T.A. Doerge, J.J Camberato, and T.J.Vyn. 2015. Anhydrous ammonia timing and rate effects on maize nitrogen use efficiencies. Agronomy Journal 107:1205-1205.

Magdoff, F.R., D. Ross, and J. Amadon. 1984. A soil test for nitrogen availability to corn. Soil Science Society of America Journal 48:1301-1304.

Marjerison, R.D., J. Melkonian, J.L. Hutson, H.M. van Es, S. Sela, L.D. Geohring, and J.Vetsch. 2016. Drainage and nitrate leaching from artificially drained maize fields simulated by the precision nitrogen management model. Journal of Environmental Quality 45:2044-2052.

McLellan, E.L., K.G. Cassman, A.J. Eagle, P.B. Woodbury, S. Sela, C. Tonitto, R.D. Marjerison, and H.M. van Es. 2018. The nitrogen balancing act: Tracking the environmental performance of food production. Bioscience 68:194-203.

Melkonian, J.J., H.M. van Es, A.T. DeGaetano, and L. Joseph, 2008. ADAPT-N: Adaptive nitrogen management for maize using high-resolution climate data and model simulations. In Proceedings of the 9th International Conference on Precision Agriculture, July 20-23, 2008, Denver, CO (CD-ROM). https://blogs.cornell.edu/ newadaptn/files/2016/06/Prec-Ag-Conf-2008Melkonian-van-Es-uhaslu.pdf.

Morris, T.F., T.S. Murrell, D.B. Beegle, J.J. Camberato, R.B. Ferguson, J. Grove, Q. Ketterings, P.M. Kyveryga, C.A. Laboski, J.M. McGrath, J.J. Meisinger, J. Melkonian, B.N. Moebius-Clune, E.D. Nafziger, D. Osmond, J.E. Sawyer, P.C. Scharf, W. Smith, J.T. Spargo, H.M. van Es, and H Yang. 2018. Strengths and limitations of nitrogen rate recommendations for corn and opportunities for improvement. Agronomy Journal 110:1-37.

NOAA (National Oceanic and Atmospheric Administration). 2017. Gulf of Mexico dead zone largest ever measured. Washington, DC: National Oceanic and Atmospheric Administration. http://www.noaa.gov/media-release/gulf-ofmexico-dead-zone-is-largest-ever-measured.

Nkebiwe, P.M., M. Weinmann, A. Bar-Tal, and T. Muller. 2016. Fertilizer placement to improve crop nutrient acquisition and yield: A review and meta-analysis. Field Crops Research 196:389-401.

Pinder, R.W., P.J Adams, and S.N. Pandis. 2007. Ammonia emission controls as a cost-effective strategy for reducing atmospheric particulate matter in the eastern United States. Environmental Science and Technology 41:380-386. 


\section{Figure 3}

(a) Cumulative nitrogen $(\mathrm{N})$ losses versus cumulative precipitation from November to V6 crop stage for all simulated eight seasons. For the spring and fall scenarios, the data include the cases when an enhanced efficiency compound was simulated. (b) Dynamics of soil inorganic $\mathbf{N}$ from November 1 (simulation time 0 ) to sidedress date at V6 growth stage (simulation time 224 days), for five $\mathrm{N}$ management scenarios. The simulated season is 2016 , with higher than average cumulative precipitation $(561 \mathrm{~mm}$ from November 1 to sidedress date).

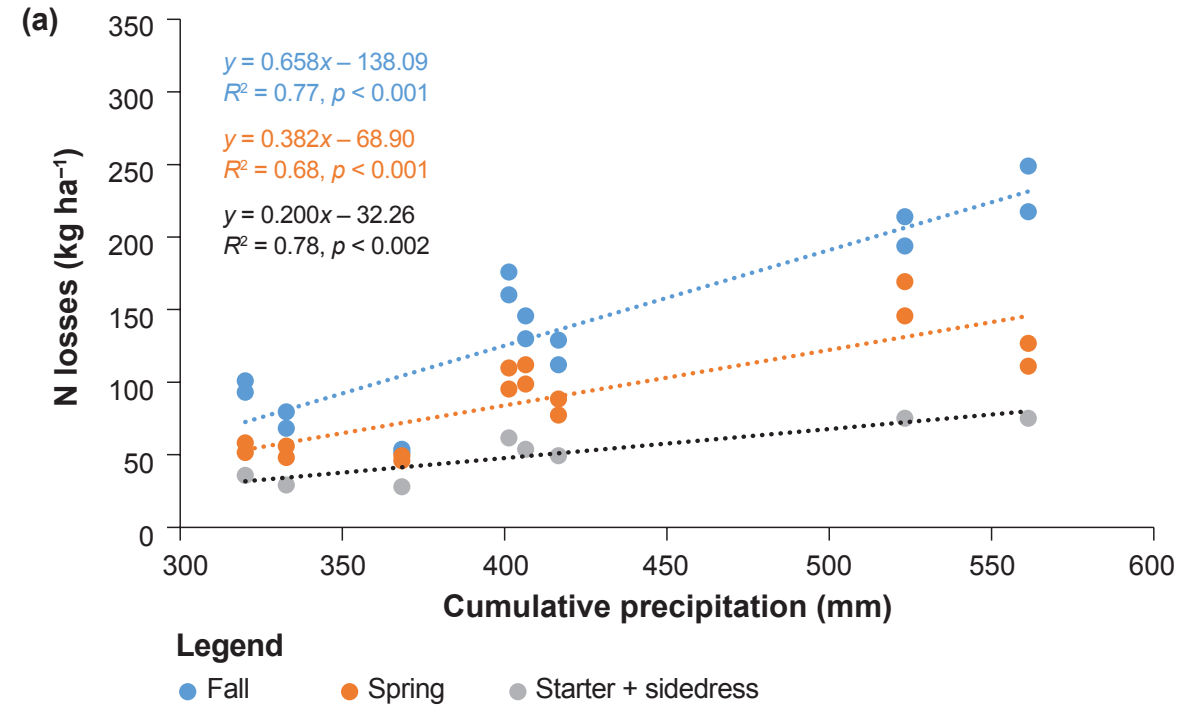

(b)

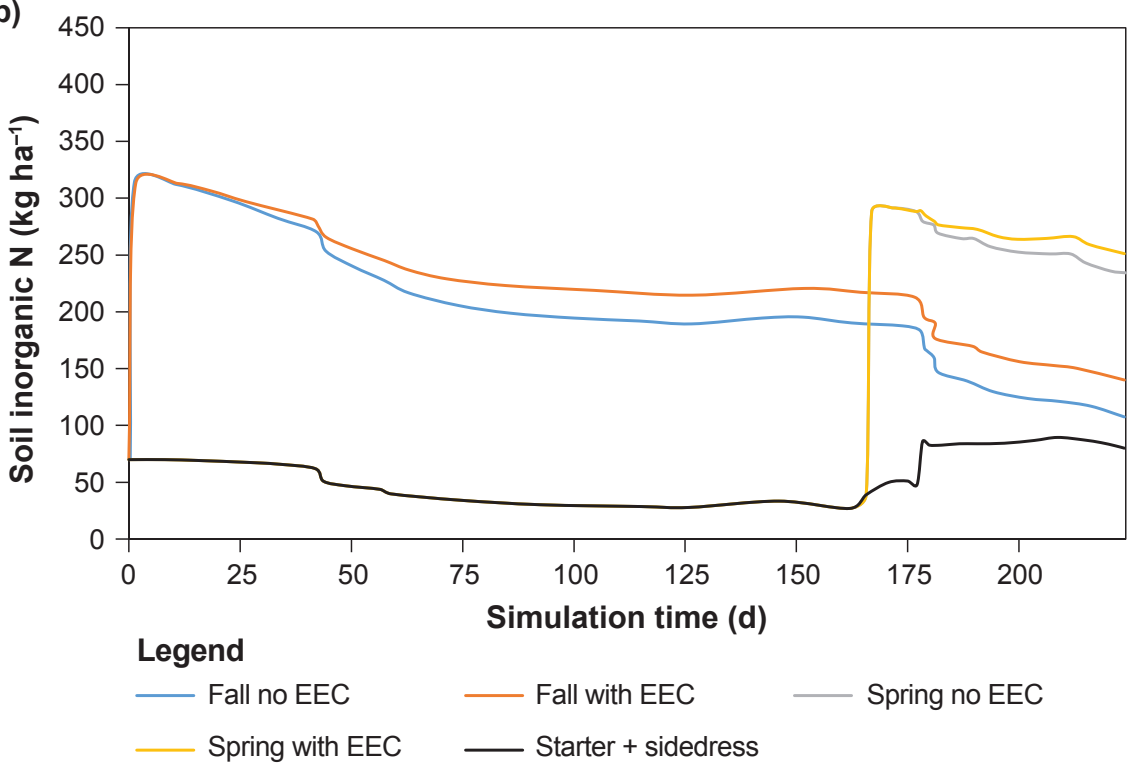

van der Schans. 2015. Maize yields benefit from injected manure positioned in bands. European Journal of Agronomy 64:29-36.

Sela, S., H.M. van Es, B.N Moebius-Clune, R. Marjerison, J. Melkonian, D. Moebius-Clune, R. Schindelbeck, and S. Gomes. 2016. Adapt-N outperforms grower-selected nitrogen rates in Northeast and Midwestern United States strip trials. Agronomy Journal 108:1726-1734.

Snyder, C., T. Bruulsema, T. Jensen, and P. Fixen. 2009. Review of greenhouse gas emissions from crop production systems and fertilizer management effects.Agriculture, Ecosystems, and Environment 133:247-266.

Sobota, D.J., J.E. Compton, M.L. McCrackin, and S. Singh. 2015. Cost of reactive nitrogen release from human activities to the environment in the United States. Environmental Research Letters 10.

TFI (The Fertilizer Institute). 2017. The 4R of Nutrient Stewardship. Washington, DC: The Fertilizer Institute. http://www.nutrientstewardship.com/4rs/.

USDA ERS (United States Department of Agriculture Economic Research Service). 2010. Tailored Reports: Crop Production Practices. Washington, DC: USDA Economic Research Service. https://data.ers.usda.gov/reports. aspx?ID $=17883$.

Westerschulte, M., C.P. Federolf, D. Trautz, G. Broll, and H.W. Olfs. 2017. Nitrogen dynamics following slurry injection in maize: Soil mineral nitrogen. Nutrient Cycling in Agroecosystems 107:1-17.

Yang, M., Y.T. Fang, D. Sun, and Y.L. Shi, 2016. Efficiency of two nitrification inhibitors (dicyandiamide and 3, 4-dimethypyrazole phosphate) on soil nitrogen transformations and plant productivity: A meta-analysis. Scientific Reports 6:22075
Pittelkow, C.M., M.W. Clover, R.G. Hoeft, E.D. Nafziger, J.J. Warren, L.C. Gonzini, and K.D. Greer. 2017. Tile drainage nitrate losses and corn yield response to fall and spring nitrogen management. Journal of Environmental Quality 46:1057-1064.

Rochette, P., D.A. Angers, M.H. Chantigny, J.D. MacDonald, M.O. Gasser, and N. Bertrand. 2009. Reducing ammonia volatilization in a no-till soil by incorporating urea and pig slurry in shal- low bands. Nutrient Cycling in Agroecosystems 84:71-80.

Scharf, P.C., D.K. Shannon, H.L. Palm, K.A. Sudduth, S.T. Drummond, N.R. Kitchen, L.J. Mueller,V.C. Hubbard, and L.F. Oliveira. 2011. Sensor-based nitrogen applications out-performed producerchosen rates for corn in on-farm demonstrations. Agronomy Journal 103:1683-1691.

Schroder,J.J., G.D.Vermeulen, J.R. van der Schoot, W. van Dijk, J.F.M. Huijsmans, G. Meuffels, and D.A. 